Kumawula, Vol. 1, No.2, Agustus 2018, Hal 104 - 113 DOI:http://10.24198/kumawula.v1i2.19929

ISSN 2620-844X (online)

Tersedia online di http://jurnal.unpad.ac.id/kumawula/index

\title{
PEMETAAN AKTIVASI BISNIS KREATIF DI KECAMATAN ANDIR
}

\author{
Ria Arifianti ${ }^{1}$, Mohammad Benny Alexandri ${ }^{2}$, Lina Auliana ${ }^{3}$ \\ ${ }^{1}$ Institusi 1, ${ }^{2}$ Institusi 2, ${ }^{3}$ Institusi 3 \\ ${ }^{1}$ email Penulis $1,{ }^{2}$ email Penulis 2, ${ }^{3}$ email Penulis 3
}

\begin{abstract}
Creative is an important component in economic growth, providing employment, trade and innovation. The increasingly alarming stagnation of economic growth and environmental degradation, encourages the whole world to prioritize creativity in economic life that maximizes the added value of a product of goods and services in the context of the sustainability of human life and civilization. For this reason, integrated construction of these sub-economic indicators is needed.

Therefore, socialization is needed for the community by doing community service. This pengambidan to the community tries to make integrated construction of the indicators of the economic sub-sector of the city of Bandung as a Creative City by integrating indicators used in other cities in the world with indicators of the activation of the existing Bandung City economic sub-sector of creativity.

The community service method is a workhop or workshop. First carried out debriefing first with existing material. Second, given Business, Third, Workshop and Evaluation Mapping and.

The results obtained were first, conducting debriefing activities. Second, the mapping was carried out in 6 sub-districts, Third, Workshop and evaluation. Evaluation was obtained as follows: participants were able to develop business activation standards. Second, the existence of public awareness to know and improve business performance. Third, Participants can measure and explain business activation. Fourth, Participants can update Business Activation in their environment.
\end{abstract}

Keywords: Economics, Creative, Business

\begin{abstract}
ABSTRAK
Kreatif merupakan komponen penting dalam pertumbuhan ekonomi, penyediaan lapangan kerja, perdangangan dan inovasi. Stagnasi pertumbuhan ekonomi dan degradasi lingkungan yang semakin mengkhawatirkan, mendorong seluruh dunia untuk lebih mengedepankan kreativitas dalam berkehidupan ekonomi yang memaksimalkan nilai tambah dari suatu produk barang dan jasa dalam rangka keberlanjutan kehidupan dan peradaban manusia. Untuk itu diperlukan kontruksi terpadu terhadap indikator-indikator sub ekonomi tersebut.

Oleh karena itu diperlukan sosialisasi kepada masyarakat dengan melakukan pengabdian kepada masyarakat. Pengambidan kepada masyarakat ini mencoba membuat kontruksi terpadu terhadap indikator-indikator sub sektor ekonomi Kota Bandung sebagai Kota Kreatif dengan cara memadukan indikator yang digunakan di Kota lain di dunia dengan indikator aktivasi sub sektor ekonomi kreativitas Kota Bandung yang sudah ada.

Metode pengabdian pada masyarakat adalah workhop atau lokakarya. Pertama dilakukan pembekalan terlebih dahulu dengan materi yang telah ada. Kedua, diberikan Pemetaan Aktivasi Bisnis, Ketiga, Lokakarya dan evaluasi dan .

Hasil yang didapat adalah pertama, melakukan kegiatan pembekalan. Kedua, pemetaan yang dilakukan di 6 kelurahan, Ketiga, Lokakarya dan evaluasi. Evaluasi didapat sebagai berikut peserta
\end{abstract}


mampu menyusun standar aktivasi bisnis, Kedua, Adanya kesadaran masyarakat mengetahui dan meningkatkan kinerja bisnis Ketiga, Peserta dapat mengukur dan menjelaskan aktivasi bisnis. Keempat, Peserta dapat update Aktivasi Bisnis di lingkungannya.

Kata Kunci : Ekonomi, Kreatif, Bisnis

\section{PENDAHULUAN}

Kreativitas, pengetahuan dan akses terhadap informasi merupakan motor penggerak pendukung pertumbuhan ekonomi dan meningkatkan pembangunan secara menyeluruh. Unsur yang muncul dalam pertumbuhan ekonomi adalah Bisnis kreatif. Bisnis kreatif yang muncul telah menjadi komponen penting dalam pertumbuhan ekonomi, danb juga mengarah pada penyediaan lapangan kerja, perdangangan dan inovasi.

Bisnis Kreatif akan menjadi trend dalam beberapa tahun mendatang. Stagnasi pertumbuhan ekonomi dan degradasi lingkungan yang semakin mengkhawatirkan, mendorong seluruh dunia untuk lebih mengedepankan kreativitas dalam berkehidupan ekonomi yang memaksimalkan nilai tambah dari suatu produk barang dan jasa dalam rangka keberlanjutan kehidupan dan peradaban manusia.

Indikator-indikator penentu kreativitas Kota Bandung perlu disempurnakan dalam hal operasionalisasi variabel pengukuran, metode pengukuran serta aktualisasi data. Kreativitas tidak saja di kota besar tetapi menjalar kepada tingkat terkecil dari pemerintahan seperti kecamatan atau kelurahan.

Salah satunya adalah Kecamatan Andir. Kecamatan Andir terletak di Bagian Bandung Barat. Potensi industri yang berada di kecamatan ini berjumlah 136 terdiri atas industri besar sebanyak 2 buah, industry sedang 42 buah, dan IKKR berjumlah 92 buah (Sri Daty, 2016, 81) Selain daripada itu terdapat pertokoan sebanyak 61 gerai dan minimarket sebanyak 51 buah. (Sri Daty, 2016, 85)

Perkembangan ini sangatlah pesat untuk ukuran suatu kecamatan. Tetapi di satu sisi, tidak masyarakat tidak mengenal produk yang dihasilkan oleh Kecamatan Andir. Khususnya industry kreatif. Hal ini sesuai wawancara dengan para pedagang, mereka mengemukakan belum bisa memasarkan barang yang mereka produksi untuk dapat dikenal di masyarakat luas khususnya Bandung.

Untuk mengatasi permasalahan tersebut diperlukan suatu sosialisasi dalam mengembangkan Salah satunya pemasarannya. Salah satu langkahnya adalah melakukan pemetaan industri yang di buat oleh para pedagang, Untuk mewujudkan hal tersebut, maka 
dilakukan dengan menggunakan pengabdian kepada masyarakat. PKM ini mencoba membuat kontruksi terpadu terhadap indikator-indikator sub sektor bisnis kreatif Kota Bandung sebagai Kota Kreatif dengan cara memadukan indikator yang digunakan di Kota lain dengan indikator aktivasi sub sektor ekonomi atau bisnis kreativitas Kota Bandung yang sudah ada.

\section{KAJIAN TEORITIS}

Suatu industri yang berasal dari pemanfaatan kreativitas, keterampilan serta bakat individu untuk menciptakan kesejahteraan serta lapangan pekerjaan dengan menghasilkan dan memberdayakan daya kreasi dan daya cipta individu tersebut dinamakan industri kreatif. Industri kreatif sejalan dengan berkembangnya ekonomi kreatif. Ekonomi kreatif yang mencakup industri kreatif telah memberikan kontribusi nyata bagi perkembangan perekonomian di sejumlah negara.

Konsep industri kreatif memberikan suatu pada terhadap perekonomian, khususnya pengaruhnya terhadap pengangguran, pembangunan regional dan dinamika kawasan urban (Andari et al., 2007; Dina, Deny 2015).

\section{Ruang lingkup dan Potensi Industri Kreatif}

Berdasarkan Instruksi Presiden Nomer 6 Tahun 2009 tentang pengembangan ekonomi kreatif terdapat 15 subsektor yang merupakan bagian dari industri kreatif :

1. Penelitian dan Pengembangan

2. Penerbitan

3. Perangkat lunak

4. TV dan Radio

5. Desain

6. Musik

7. Film

8. Permainan dan Games

9. Jasa Periklanan

10. Arsitetur

11. Seni Pertunjukkan

12. Kerajinan

13. Fesyen

14. Seni Rupa 
Ruang lingkup ekonomi kreatif di Indonesia berdasarkan Inpres Nomor 6 Tahun 2009 adalah sebagai berikut:

1) Periklanan (advertising): kegiatan kreatif yang berkaitan dengan jasa periklanan, yakni komunikasi satu arah dengan menggunakan medium tertentu. Meliputi proses kreasi, operasi, dan distribusi dari periklanan yang dihasilkan, misalnya riset pasar, perencanaan komunikasi periklanan, media periklanan luar ruang, produksi material periklanan, promosi dan kampanye relasi publik. Selain itu, tampilan periklanan di media cetak (surat kabar dan majalah) dan elektronik (televisi dan radio), pemasangan berbagai poster dan gambar, penyebaran selebaran, pamflet, edaran, brosur dan media reklame sejenis lainnya, distribusi dan delivery advertising materials or samples, serta penyewaan kolom untuk iklan;

2) Arsitektur: kegiatan kreatif yang berkaitan dengan desain bangunan secara menyeluruh, baik dari level makro (town planning, urban design, landscape architecture) sampai level mikro (detail konstruksi). Misalnya arsitektur taman, perencanaan kota, perencanaan biaya konstruksi, konservasi bangunan warisan sejarah, pengawasan konstruksi, perencanaan kota, konsultasi kegiatan teknik dan rekayasa seperti bangunan sipil dan rekayasa mekanika dan elektrikal;

3) Pasar Barang Seni: kegiatan kreatif yang berkaitan dengan perdagangan barang-barang asli, unik dan langka serta memiliki nilai estetika seni dan sejarah yang tinggi melalui lelang, galeri, toko, pasar swalayan dan internet, meliputi barang-barang musik, percetakan, kerajinan, automobile, dan film;

4) Kerajinan (craft): kegiatan kreatif yang berkaitan dengan kreasi, produksi dan distribusi produk yang dibuat atau dihasilkan oleh tenaga pengrajin yang berawal dari desain awal sampai proses penyelesaian produknya. Antara lain meliputi barang kerajinan yang terbuat dari batu berharga, serat alam maupun buatan, kulit, rotan, bambu, kayu, logam (emas, perak, tembaga, perunggu dan besi), kaca, porselen, kain, marmer, tanah liat, dan kapur. Produk kerajinan pada umumnya hanya diproduksi dalam jumlah yang relatif kecil (bukan produksi massal);

5) Desain: kegiatan kreatif yang terkait dengan kreasi desain grafis, desain interior, desain produk, desain industri, konsultasi identitas perusahaan dan jasa riset pemasaran serta produksi kemasan dan jasa pengepakan; 
6) Fesyen (fashion): kegiatan kreatif yang terkait dengan kreasi desain pakaian, desain alas kaki, dan desain aksesoris mode lainnya, produksi pakaian mode dan aksesorisnya, konsultasi lini produk berikut distribusi produk fesyen;

7) Video, Film dan Fotografi: kegiatan kreatif yang terkait dengan kreasi produksi video, film, dan jasa fotografi, serta distribusi rekaman video dan film. Termasuk di dalamnya penulisan skrip, dubbing film, sinematografi, sinetron, dan eksibisi atau festival film;

8) Permainan Interaktif (game): kegiatan kreatif yang berkaitan dengan kreasi, produksi, dan distribusi permainan komputer dan video yang bersifat hiburan, ketangkasan, dan edukasi. Sub-sektor permainan interaktif bukan didominasi sebagai hiburan semata-mata tetapi juga sebagai alat bantu pembelajaran atau edukasi;

9) Musik: kegiatan kreatif yang berkaitan dengan kreasi atau komposisi, pertunjukkan, reproduksi, dan distribusi dari rekaman suara;

10) Seni Pertunjukkan (showbiz): kegiatan kreatif yang berkaitan dengan usaha pengembangan konten, produksi pertunjukkan. Misalnya, pertunjukkan wayang, balet, tarian tradisional, tarian kontemporer, drama, musik tradisional, musik teater, opera, termasuk musik etnik, desain dan pembuatan busana pertunjukkan, tata panggung, dan tata pencahayaan;

11) Penerbitan dan Percetakan: kegiatan kreatif yang terkait dengan penulisan konten dan penerbitan buku, jurnal, koran, majalah, tabloid, dan konten digital serta kegiatan kantor berita dan pencari berita. Subsektor ini juga mencakup penerbitan perangko, materai, uang kertas, blanko cek, giro, surat andil, obligasi, saham dan surat berharga lainnya, paspor, tiket pesawat terbang, dan terbitan khusus lainnya. Juga mencakup penerbitan foto-foto, grafir (engraving) dan kartu pos, formulir, poster, reproduksi, percetakan lukisan, dan barang cetakan lainnya, termasuk rekaman mikro film;

12) Layanan Komputer dan Piranti Lunak (software): kegiatan kreatif yang terkait dengan pengembangan teknologi informasi, termasuk layanan jasa komputer, pengolahan data, pengembangan database, pengembangan piranti lunak, integrasi sistem, desain dan analisis sistem, desain arsitektur piranti lunak, desain prasarana piranti lunak dan piranti keras, serta desain portal termasuk perawatannya;

13) Televisi \& Radio (broadcasting): kegiatan kreatif yang berkaitan dengan usaha kreasi, produksi dan pengemasan acara televisi (seperti games, kuis, reality show, infotainment, dan lainnya), penyiaran, dan transmisi konten acara televisi dan radio, termasuk kegiatan station relay (pemancar) siaran radio dan televisi; 
14) Riset dan Pengembangan (R\&D): kegiatan kreatif terkait dengan usaha inovatif yang menawarkan penemuan ilmu dan teknologi, serta mengambil manfaat terapan dari ilmu dan teknologi tersebut guna perbaikan produk dan kreasi produk baru, proses baru, material baru, alat baru, metode baru, dan teknologi baru yang dapat memenuhi kebutuhan pasar. Termasuk yang berkaitan dengan humaniora, seperti penelitian dan pengembangan bahasa, sastra, dan seni serta jasa konsultansi bisnis dan manajemen.

\section{METODE}

Metode pendekatan adalah Lokakarya atau workshop. Workshop adalah pertemuan untuk bertukar pengetahuan dan pengalaman diantara sejumlah peserta yang mempunyai keahlian atau profesi yang sama, guna meningkatkan pengetahuan atau memecahkan suatu masalah. Workshop merupakjan duatu pelatihan untuk peserta secara individu atau berkelompok untuk memecahkan masalah. (Wikipedia, 2017) Dalam hal ini peserta workshop adalah perwakilan dari 6 kelurahan yang ada di Kecamatan Andir.

Dalam pelaksanaan PKM dilakukan dengan tiga tahap. :

Pertama dilakukan pembekalan terlebih dahulu dengan materi yang telah ada.

Kedua, dilakukan pelaksanaan pemetaan

Ketiga, Lokakarya dan evaluasi.

\section{HASIL DAN PEMBAHASAN}

Pelaksanaan pemetaan aktivasi Bisnis Kreatif Di Kecamatan Andir dilakukan sebagai berikut :

\section{Melakukan Pembekalan.}

Pembekalan dilakukan dengan cara memberikan materi bagaimana melakukan aktivasi bisnis yang mereka kelola. Pembekalan ini dilakukan dengan membagi 6 kelompok berdasarkan jumlah kelurahan di Kecamatan Andir. Pihak yang terkait adalah bagian yang terkait dengan industri, dan perwakilan dari masing-masing kelurahan.

\section{Pemetaan}

Pemetaan dilakukan dengan cara melakukan pengambilan data jumlah industri berdasarkan kelurahan. Setiap kelompok dalam melakukan pengambilan data dipandu oleh seorang petugas kecamatan dan seorang anggota keliurahan yang terkait. Pengambilan data ini dilakukan secara serentak dan memakan waktu sekitar 1 bulan. Hal ini disertai dengan wawancara ke setiap pedagang atau pelaku industri. Selain itu, kelompok memandu cara- 
cara melakukan pemetaan terhadap para pelaku industri.

\section{Hasil dari pemetaan sebagai berikut :}

Kecamatan Andir merupakan salah satu bagian wilayah Barat Kota Bandung dengan memiliki luas lahan sebesar 370,74 Ha. Secara administratif Kecamatan Andir dibatasi oleh :

- Bagian Selatan : Kecamatan Astana Anyar, Bojongloa Kaler, Bbk. Ciparay, Bandung Kulon, Kota Bandung

- Bagian Utara : Kecamatan Cicendo Kota Bandung

- Bagian Timur : Kecamatan Sumur Bandung, Kota Bandung

- Bagian Barat : Kecamatan Cimahi Selatan, Kota Cimahi

Kecamatan Andir terdiri dari 6 kelurahan yaitu Kelurahan Kebon Jeruk, Kelurahan Ciroyom, Kelurahan Dunguscariang, Kelurahan Garuda, Kelurahan Maleber, Kelurahan Campaka. Secara geografis Kecamatan Andir memiliki bentuk wilayah datar / sebesar 100\% dari total keseluruhan luas wilayah. Ditinjau dari sudut ketinggian tanah, Kecamatan Andir berada pada ketinggian 700m di atas permukaan air laut. Selanjutnya data kegiatan bisnis di Kecamatan Andir sebagai berikut :

Tabel 4.1.

Jumlah Bisnis di Kecamatan Andir

\begin{tabular}{|l|l|c|c|}
\hline No. & \multicolumn{1}{|c|}{ Kelurahan } & Jumlah UMKM & Jumlah Bisnis Kreatif \\
\hline 1 & Kebon Jeruk & - & 1 \\
\hline 2 & Ciroyom & - & 1 \\
\hline 3 & Dunguscariang & 85 & 2 \\
\hline 4 & Garuda & 9 & 1 \\
\hline 5 & Maleber & 9 & 2 \\
\hline 6 & Campaka & 78 & 1 \\
\hline & Jumlah & $\mathbf{1 8 1}$ & $\mathbf{8}$ \\
\hline
\end{tabular}

\section{Sumber : Hasil Survei, 2018}

\section{Lokakarya dan Evaluasi}

Kegiatan Lokakarya dilakukan di Kecamatan Andir. Teknis lokakarya adalah dengan memaparkan hasil yang di dapat dan sekaligus melakukan evaluasi. Selain itu mendapat masukan-masukan dari pihak Kecamatan dan Kelurahan. Peserta lokakarya ini adalah Camat, 
Sekretaris Camat beserta staf yang terkait. Peserta juga dihadiri oleh para Lurah beserta Staf. Jumlah anggota yang dating adalah 60 orang.

Pengabdian pada masyarakat dengan tujuan untuk mengaplikasikan ilmu yang dipunyai kepada masyarakat. Dalam pelaksanaan PKM ini melibatkan masyarakat di daerah Kecamatan Andir. Para peserta dapat memahami dan dapat menyusun standar aktivasi bisnis industri kreatif di bidang masing-masing. Adapun untuk pelatihan evaluasi indikator dan pencapaian yang ingin dicapai adalah :

Tabel 4.2.

\section{Indikator Pencapaian}

\begin{tabular}{|c|c|c|}
\hline No & Sebelum & Pencapaian setelah kegiatan \\
\hline 1. & $\begin{array}{l}\text { Aktivasi Bisnis disusun sebagai alat Pemerintah dan } \\
\text { Pemerintahan Daerah untuk menjamin akses dan } \\
\text { data kepada bisnis yang ada di kecamatannya. }\end{array}$ & $\begin{array}{l}\text { Peserta mampu menyusun } \\
\text { standar aktivasi bisnis }\end{array}$ \\
\hline No & Sebelum & Pencapaian setelah kegiatan \\
\hline 2. & $\begin{array}{l}\text { Indikator Aktivasi ditetapkan oleh Pemerintah dan } \\
\text { diberlakukan untuk seluruh Pemerintahan Daerah } \\
\text { Provinsi dan Pemerintahan Daerah Kabupaten/ } \\
\text { Kota. }\end{array}$ & $\begin{array}{l}\text { Peserta muncul kesadaran } \\
\text { mengetahui dan meningkatkan } \\
\text { kinerja bisnis }\end{array}$ \\
\hline 3 & $\begin{array}{l}\text { Aktivasi Bisnis bersifat sederhana, konkrit, mudah } \\
\text { diukur, terbuka, terjangkau dan dapat } \\
\text { dipertanggungjawabkan serta mempunyai batas } \\
\text { waktu pencapaian. }\end{array}$ & $\begin{array}{l}\text { Peserta dapat } \\
\text { aktivasi bisnis }\end{array}$ \\
\hline 4 & $\begin{array}{l}\text { Aktivasi Bisnis disesuaikan dengan perkembangan } \\
\text { kebutuhan, prioritas dan kemampuan keuangan } \\
\text { nasional dan daerah serta kemampuan kelembagaan } \\
\text { dan personil daerah dalam bidang yang } \\
\text { bersangkutan. }\end{array}$ & $\begin{array}{l}\text { Peserta dapat update Aktivasi } \\
\text { Bisnis di lingkungannya }\end{array}$ \\
\hline
\end{tabular}

Dalam melakukan kegiatan bisnis, program-program pemerintah dalam bidang industri kreatif tidak begitu berjalan dengan baik. Hal ini dikarenakan masyarakat cenderung berperilaku pasif atau tidak berpartisipasi terhadap program-program pemerintah dalam bidang ekonomi kreatif. Di lain sisi, masyarakat yang telah berpartisipasi dalam program tersebut dinilai belum mampu menjalankan bisnis mereka secara mandiri. Sebagi contoh adanya bisnis tidak lanjut berjalan saat bimbingan dari pemerintah selesai.

Pelaku bisnis kreatif masih belum mampu bersaing dengan pelaku bisnis yang jauh lebih besar atau unggul. Hal ini disebabkan oleh rendahnya motivasi mereka untuk mengembangkan bisnisnya. Berdasarkan hasil wawancara, sebagian besar dari pelaku bisnis masih belum 
mempunyai strategi dalam mengembangkan bisnisnya, padahal strategi sangat penting untuk mengembangkan bisnis. Beberapa aspek seperti pembentukan tim, relasi, pengelolaan keuangan, pemasaran, dan lain-lain masih belum dilaksanakan dengan maksimal. Oleh karena kitu diperlukan pelatihan dalam bidang bisnis kreatif.

Pengabdian masyarakat adalah sebuah bentuk sosialisasi dan aktualisasi diri dosen dengan ilmu yang dipunyai dan diaplikasikan ditengah-tengah masyarakat. Walaupun kegiatan pengabdian masyarakat yang biasanya dilakukan identik dengan keterbatasan dana, namun hasil harus memberikan manfaat sebanyak mungkin terhadap masyarakat yang menjadi sasaran. Sehingga dalam menyelenggarakan pengabdian kepada masyarakat dibutuhkan inovasi dan kreatifitas yang dalam mengkonsep kegiatan-kegiatan yang terkandung dalam programprogram yang ditawarkan.

Kegiatan-kegiatan pengabdian masyarakat akan memberikan dampak yang positif terhadap dosen yang bersangkutan dan masyarakat. Dengan segala potensi, intelegensia, kreativitas yang ada serta melihat peran dari dosen baik sebagai agent of change, dan moral force dengan adanya dukungan fasilitas dan wadah dari universitas untuk melakukan kegiatan pengabdian masyarakat.

\section{SIMPULAN}

1. Pembekalan dilakukan dengan memberikan materi yang akan dilaksanakan

2. Pemetaan dilakukan dengan pengumpulan data dan memandu para pelaku industri untuk melakukan cara pemetaan.

3. Dengan adanya pemetaan, maka para pelaku industri dapat melakukan kegiatan pemetaan meskipun belum berjalan dengan baik

\section{DAFTAR PUSTAKA}

Andari, R., H. Bakhshi, W. Hutton, A. O’Keeffe, P. Schneider, 2007, Staying Ahead: The economic performance of the UK's Creative Industries, The Work Foundation, London

Dina Melita, Deni Erlansyah. Andari, R., (2015), Pemetaan Industri Kreatif Dalam Meningkatkan Pertumbuhan Ekonomi Kawasan Urban Di Kota Palembang. Proceding Economic Globalization Trend and Risk For Developing Country

, 2009. Instruksi Presiden Nomer 6 Tahun 2009 tentang pengembangan ekonomi kreatif 
Sri Daty, (2016), Andir Dalam Angka, Badan Pusat Statistik, Bandung

Sugiyono (2012), Metode Penelitian Kualitatif, Alfabeta, Bandung Wikipedia, 2017. 